\title{
23. On the origin of the verb ötün - and its derivatives in the historical Turkish dialects
}

\section{Berker KESKIN ${ }^{1}$}

APA: Keskin, B. (2021). On the origin of the verb ötün - and its derivatives in the historical Turkish dialects. RumeliDE Dil ve Edebiyat Araştırmalar Dergisi, (24), 442-455. DOI: 10.29000/rumelide.995321.

\begin{abstract}
The verb ötün-, which basically means "to submit, to request, to ask", has been encountered in the texts since the Old Turkish period. Especially in the Old Uyghur Turkish, it is seen that the frequency of use of the verb with its various derivatives increased, but we can find it in all historical Turkish dialects, and it still maintains its existence in a significant part of modern Turkish dialects. It is clear that the verb is not in the form of a base, and for this reason, various views have been put forward about its structure. However, there is no consensus on the subject yet. In this study, first of all, I aim to question the status of the verb in the historical dialects and then show its existence in the modern dialects. I have brought together the explanations made so far about the verb base and presented the common theme. Then, based on the existing data I have examined what the verb base might be. Finally, I have explained the derivatives of this verb base in the historical dialects of Turkish with examples.
\end{abstract}

Keywords: Ötünmäk, etymology, history of Turkish Language, historical Turkish dialects

\section{Ötün - eyleminin kökeni ve tarihi Türk lehçelerindeki türevleri üzerine}

\section{$\ddot{O} \mathbf{z}$}

Temel olarak "arz etmek, ricada bulunmak, istemek" anlamlarına sahip olan ötün- eylemi, Eski Türkçe dönemi metinlerinden itibaren karşımıza çıkmaktadır. Özellikle Eski Uygur Türkçesinde çeşitli türevleriyle birlikte eylemin kullanım sıklı̆̆ının arttı̆̆ı görülür, ancak tüm tarihi Türk lehçelerinde bunu bulabildiğimiz gibi çağdaş Türk lehçelerinin önemli bir kısmında da hâlâ varlığını korumaktadır. Eylemin kök halinde olmadı̆̆ı açıktır ve bu sebeple yapısı hakkında pek çok görüş ortaya konmuştur. Bununla birlikte konu hakkında henüz bir fikir birliği bulunmamaktadır. Benim bu çalışmadaki amacım, öncelikle eylemin tarihi lehçelerdeki durumunu sorgulamak ve ardından çă̆daş lehçelerdeki varlığını göstermektir. Eylemin kökeni hakkında bugüne kadar yapılan açıklamaları bir araya getirerek genel durumu sundum ve mevcut verilerden hareketle kökün ne olabileceği hakkında belli bir değerlendirmede bulundum. Son olarak, ortaya koyduğum bu eylem kökünün tarihi Türk lehçelerinde hangi türevlere sahip olduğunu örnekleriyle birlikte açıkladım.

Anahtar kelimeler: Ötünmäk, köken bilgisi, Türk dili tarihi, tarihi Türk lehçeleri

Arş. Gör. Dr., İstanbul Üniversitesi, Edebiyat Fakültesi, Türk Dili ve Edebiyatı Bölümü (İstanbul, Türkiye), berker.keskin@istanbul.edu.tr, ORCID ID: 00oo-ooo1-8599-286X [Araştırma makalesi, Makale kaylt tarihi: 11.08.2021kabul tarihi: 20.09.2021; DOI: 10.29000/rumelide.995321]

Adres $\mid$ Address

RumeliDE Dil ve Edebiyat Araşturmaları Dergisi $\quad$ RumeliDE Journal of Language and Literature Studies Osmanağa Mahallesi, Mürver Çiçeği Sokak, No:14/8 Osmanağa Mahallesi, Mürver Çiçeği Sokak, No:14/8 Kadıköy - ÍSTANBUL / TÜRKIYE 34714 Kadıköy - ISTANBUL / TURKEY 34714 e-posta: editor@rumelide.com e-mail: editor@rumelide.com, tel: +90 505 7958124, +90 2167730616 phone: +90 505 7958124, +90 2167730616 


\section{Ø. Introduction}

The Old Turkish period of the Turkish language includes the monumental texts of Orkhon Turkish engraved in stone, the literary complete works of Old Uyghur language that emerged due to contact with different cultures, and texts written on various subjects such as law, astronomy and medicine. In the $11^{\text {th }}$ century, when the Islam was widely accepted by the Turkish nation, Karakhanid Turkish was also shaped by its predecessors, Orkhon and Uyghur Turkish. Middle Turkish is a period in which the dialects are more mixed and diversified. While many religious and literary works were prepared in Khwarazm Turkish, an example of this dialect mix, Kipchak Turkish continued its existence as Steppe Kipchak in the North and Mamluk Kipchak in the South. Especially with 'Alī Shīr Navāìì, Chagatai Turkish gained the characteristic of being the prestige language and was also called Eastern Turkish.

Based on the texts that have survived to the present day, we can easily state that the Turkish language has a rich vocabulary in the Old Turkish period. A verb from this vocabulary, ötün-, is the subject of this study. I will present respectively the meaning and history of the verb, its existence in the historical and modern Turkish dialects, and the views on its etymology. Then I will make an evaluation of the etymology and will determine the derivatives of the verb base in historical Turkish dialects.

\section{I. Ötün- in the historical and modern Turkish dialects}

The verb ötün- basically means "to submit, to request, to ask, to show respect (to an elder)" and can be identified in Old Turkish as a main verb onwards the Köktürk texts: anta ötrü kaganıma ötüntüm (T I / S-5). "Then, I submitted to my Khan." tokuz buyruk [b]e[š] säyüt kara bodun turayın kayım kanka ötünti (Tar. / S-4). “...the nine commands, five generals and the people came before my father and submitted to my father, Khan.”

It is possible to see that the verb is found in many works of this period as a natural result of the fact that the texts from Old Uyghur Turkish are more in number. Furthermore, another reason for this situation is the religious content of the works. In other words, as a structural feature in Old Uyghur works based on the translation of various texts belonging to religions such as Buddhism and Manichaeism, there are many questions and situations that disciples or students "submit" or "ask" to their religious elders or masters, and ötün- is often used to meet this: alknčsız kögüzlüg bodisvt yana ikiläyü ötünti (KuanTekin $\left.{ }_{159-160}\right)$. "Bodhisattva the Infinitely Voluntary again submitted a second time."

In this period, ötün- was used not only as of the main verb but also as a descriptive auxiliary verb. In other words, the verb ötün- means the action of the main verb took place respectfully:² ikigü kälip samsto ačarika köyül ayıtmak tıltagınta ötrü ayıtu ötüntilär (HT VIII ${ }_{1439-1441}$ ) “...the two came to learn his opinion and wished to ask Master Samsto.” bo ikinti bilmȘtin yaz(ı)nmı̌ yazokug bošunu ötünür biz (Huast ${ }_{66-68}$ ) “...we ask forgiveness for this second unknowing sin.”

Descriptive auxiliary verbs come after the main verb in the sentence and contribute to the explanation of the verb shown by the main verb. Annemarie von Gabain characterized the verbs tägin- and yarlıka- along with ötün- as "modal verbs of respect" (1950: 130). Şinasi Tekin attributed the increase in descriptive auxiliary verbs, especially in the Old Uyghur period, to the foreign languages in which the translations were made, although the verbs had a single meaning in Orkhon Turkish (2002: 98). Marcel Erdal evaluated the auxiliary verbs yarlika-, ötün- and tägin- showing the subject's social position with the title of Reflection of Social Structure and stated the verb tägin- together with ötün- is used to show the speech and actions of individuals with lower status, respectively (2004: 529). As a result, it should be understood that there is a situation of submission, request or respect if ötün- in the sentence improves the main verb in terms of meaning (Eraslan, 2012: 446).

RumeliDE Dil ve Edebiyat Araştırmaları Dergisi Osmanağa Mahallesi, Mürver Çiçeği Sokak, No:14/8 Kadıköy - ISTANBUL / TÜRKIYE 34714 e-posta: editor@rumelide.com tel: +90 $5057958124,+902167730616$
Address

RumeliDE Journal of Language and Literature Studies

Osmanağa Mahallesi, Mürver Çiçeği Sokak, No:14/8

Kadıköy - ISTANBUL / TURKEY 34714

e-mail: editor@rumelide.com,

phone: +90 505 7958124, +90 2167730616 
There are examples showing that the verb is used in hendiadys with synonyms or similar verbs such as ayıt- "to ask", kol- "to request and want", sözlä- "to tell" and yalbar- "to beg”.3

In addition, it took part in various compound verb forms during this period and was also used as an auxiliary verb to meet the meaning "to submit, to request, to ask": ikinti ärsär bo nom ärdinikä takı artukrak süzülgülük ärtipü k(ä)rgäk-lig ötüg ötüntüy (AY Kaya $449 / 8-10$ ). “...secondly, thanks to this jewel of teaching, you have made a very necessary sentence to be purified greatly.”

In the Karakhanid Turkish period, when the first Islamic works in the Turkish language were prepared, the verb ötün- continued to be used in its basic meaning "to submit, to request, to ask": saya söz ayıtsa ötün söz čml/cävab bersä yarhg tägürgil köni $\left(\mathrm{KB}_{4060}\right)$. "If he asks you a word, tell the truth. If he answers, follow his order correctly." aya til törüt mädḥ ötüngil kanı $\left(\mathrm{AH}_{41}\right)$. "O tongue! Create and tell compliments! Well?" Regarding the verb described as "to tell (something to the Khan)" not only in literary works but also in DLT, the first known dictionary of Turkish, it is possible to see that the sentence ol xānka ötüg ötündi "He presented his (status) to the Khan" is given as an example (Ercilasun \& Akkoyunlu, 2014: 98).

Besides, the verb is used in the same way in Khwarazm, Golden Horde Turkish and Chagatai Turkish after Karakhanid Turkish: öyni hāă ḳılg̀ıl, bu kečä rāzım niyāzımn bì-niyāa mäliknī ḥażrät[idä] ötünäyin $\left(\mathrm{KE}_{218 \mathrm{v} / 20-21}\right)$ “...evacuate the house, let me present my secret and supplication in the presence

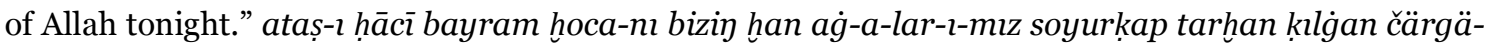
sin aylața öțündü ärsä (AOY $\mathrm{II}_{16-19}$ ) “...if he submitted to respectively tell to his father, Hacı Bayram Hodja that our aga khans bestow and make tarhan...” anda kedin väzīr mälik hididmätigä ötünüp ayttı $\left(\mathrm{GT}_{39 / 4-5}\right)$ "Then, the vizier submitted and said before the ruler."

The existence of the verb in Old Anatolian Turkish, the first period of Western Turkish, is quite limited. There are two examples of it in Ali's Kıssa-i Yūsuf, one of the mixed language works: ol zāhid bu aḥval

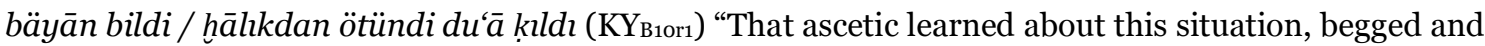

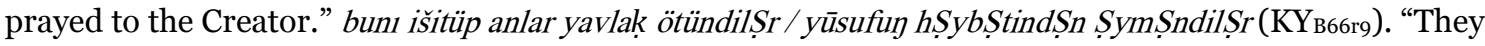
heard this and submitted it a lot, they were afraid of Yusuf's majesty." Although it is stated in the TS that the verb took place in the Dīwān of Lâmiî Chelebi, one of the $16^{\text {th }}$-century Ottoman poets (V, 1996: 3138), it is understood that this is actually ن̛ ${ }^{\prime}$ ' utan in the IU copy of the work (Lâmiî Chelebi, Dîvân-ı Lâmiû, IU Rare Works Library No: 671, fol. 71b).

There is no evidence of the existence of the verb ötün- in standard Turkish spoken in Turkey, since it was replaced by compound verbs such as arz etmek and rica etmek. However, when traced in the dialects, it is seen that the immigrants of Idyll-Ural used the verb as "begging, wishing" (DS V, 2019: 3361a) and similarly the verb is used in Antakya region as "begging, piling on the agony" (DS VI, 2019: 4631a).

The verb continues to exist, for example, in the form of ütĕn- in Bashkir (Özşahin, 2017: 675b), vidĕnin Chuvash (Skvorcova, 1982: 82), ötin- in Karakalpak (Baskakova, 1958: 515b), ötin- in Kazakh (Shnitnikov, 1966: 295a), ütĕn- in Kazan Tatar (Öner, 2009: 316b), ötün- in Kyrgyz (Judaxin, 1985: 104a), otin- in Uzbek (Borovkova, 1959: 589b), ötün- in Turkmen (Baskakova, 1968: 508a) and ötün- in Uyghur (Necip, 1995: 309a), apart from Turkey Turkish.

\footnotetext{
3 For all other hendiadyses with ötün- see Şen, 2002: 163, 228-229, 340 and Ölmez, 2017: 263, 273, 283-284, 302.

Adres Address

RumeliDE Dil ve Edebiyat Araştrmaları Dergisi $\quad$ RumeliDE Journal of Language and Literature Studies Osmanağa Mahallesi, Mürver Ciçeği Sokak, No:14/8 Osmanağa Mahallesi, Mürver Çiçeği Sokak, No:14/8 Kadıköy - İSTANBUL / TÜRKIYE 34714 Kadıköy - ISTANBUL / TURKEY 34714 e-posta: editor@rumelide.com e-mail: editor@rumelide.com, tel: +90 $5057958124,+90216773$ o 616 phone: +90 505 7958124, +90 216773 o 616
} 


\section{II. Ötün- in dictionary and other studies}

Gabain described the verb ötün- as "to show respect, to do something unselfishly" and attributed its base to the verb öt- which meant "to request" (1950: 81).

Ahmet Caferoğlu stated that the meanings of the verb ötün- are "(1) To make someone regret, to make someone feel sorry. (2) To make a request, to wish, the addressing of the younger to the elder." in the Old Uyghur Turkish Dictionary (1968: 155). Although there is no information about etymology here, when we go to the entry ötmäk, we see that the second meaning given by Caferoğlu to this verb is "to ask, to wish" (1968: 154). However, there is no source of information for this meaning given to the verb ötmäk in the dictionary cited for almost every explanation.

In DTS the verb ötün- has been stated "to address someone, to apply; to ask, to request" (Nadaljaev et al., 1969: 393b).

Sir Gerard Clauson stated that it is the reflexive form of a verb that comes from the same base with words such as ötüg and gave the meanings of "to submit a statement or request to a superior; to request, pray" (1972: 62a). In the entry Ötüg (II), Clauson, who gave the meaning of "request, memorial to a superior", stated that the base of the word is uncertain and emphasized two possibilities regarding this. Accordingly, the base of the word is either öti- ötü-, which is not currently present in the Turkish language or the verb öt- that directly means "to go by, to pass by" (1972: 51a).

E. V. Sevortjan states that the verb whose meanings "(1) To ask, to make a request. (2) To implore, to beg. (3) To address. (4) To ask for forgiveness. (5) To offer (gifts). (6) To trust, to hope." are listed is the reflexive form of the verb öt- (II) which also means "to speak, to communicate, to ask" as its oldest meanings (1974: 557). We see that the author provides meanings such as "to sing, to make a sound, to say” for öt- (II) (1974: 556).

Erdal states that the verb which he gives the meaning "to present something to a superior (a king, a master, a spiritual leader, etc.); to request and to beg" is probably derived from the verb öt- "to pass through, to penetrate, pass off" (1991: 611).

According to James Russel Hamilton, the verb can be a - $n$ - reflexive or middle voice of the verb ötmeaning "to pass through, to convey" or *öt- meaning "to make think" rather than the verb öt- "to sing" (1998: 211).

Talat Tekin explained the verb ötün- as "to submit, to make a request" and stated that its base is an *ötwhose existence cannot be determined (2003: 94).

Eraslan analyzed the verb ötün- in the Dictionary section of the Old Uyghur grammar (< öt-ü-n-) and stated that the verb has the meaning "to request, to ask a favor, to make a wish; to pray, to submit, to present, to beg" (2012: 597). According to this analysis, when we go to the entry öt-, we see that the author, like Caferoğlu, gives the meaning "to pass, to request, to wish" to the verb öt- (2012: 596).

Based on the examples of ...ötüg ötüy in Maitrisimit and ...ötti by Erdal (1991: 611), Mehmet Mahur Tulum attributes the base of the noun ötüg and the verb ötün- to the different verb öt- that belongs to the concept of request and desire (2015: 473).

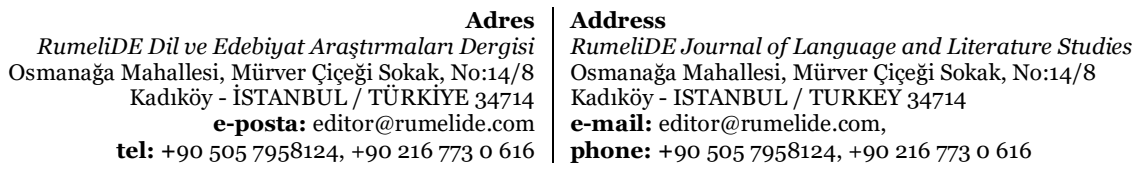


Ümit Özgür Demirci explained the verb that he gave the meanings of "to submit, to request, to respect, to pray, to present" as *öt-(ü)n- based on OTWF. He also stated that the example written as ötüy in Maitrisimit is a possible spelling error, because he could not detect the verb öt- meaning "to request, to ask for, to wish", and the word that was written ötüy should actually be in the form of ötünüy (2016: 441).

In a footnote, Ahmet Bican Ercilasun added to the entry ötkünč of the DLT, he stated that the word ötüg with the verb ötkün- "to tell a story" may have been derived from an act in the form of *ötü- (Ercilasun \& Akkoyunlu, 2014: 82).

Jens Wilkens, in his dictionary, discussed the meanings of the verb ötün- in detail (2021: 544b) and stated that the verb öt- could not be the verb base, and explained that it is "an old mistake for ${ }^{1}$ ötün-" (2021: 543a).

\section{Towards the base}

In parallel to the explanations above, it is clear that there is no problem with the meanings of the verb ötün-. The main issue is to determine what the base of the verb is. The following table summarizes of the current opinions on the verb ötün-:

\begin{tabular}{|c|c|c|c|}
\hline Verb & Base & Meaning & Author(s) \\
\hline ötün- & $<\ddot{o t}-$ & "to wish, to request" & Gabain, 1950: 81; Caferoğlu, 1968: 154; Eraslan, 2012: 596 \\
\hline ötün- & $<\ddot{o t}-$ & "to pass" & Clauson, 1972: 51a; Erdal, 1991: 611; Hamilton 1998: 211 \\
\hline ötün- & $<\ddot{o t}-$ & "to sing, make a sound" & Sevortjan, 1974: 556 \\
\hline ötün- & $<* \ddot{o t}-$ & "make think" & Hamilton, 1998: 211 \\
\hline ötün- & $<* \ddot{o} t-$ & & Tekin, 2003: 94 \\
\hline ötün- & $<* \ddot{o t} t-\sim * \ddot{o} t \ddot{u}-$ & & Clauson, 1972: 51a; Ercilasun \& Akkoyunlu, 2014: 82 \\
\hline
\end{tabular}

I would like to quote all of the sentences that the verb öt-is understood to be used independently in the sense of "to ask, to wish" and are also pointed out as examples by both Erdal and Tulum:

tükäl bilgä tägri täyrisi burkan tapa barp inčä tep ötüg ötüy (Maitr ${ }_{91 / 25-27}$ ) “Go towards Buddha, the utterly wise, god of gods, and submit it like this."

či-nak inčä tep ötti (ChristManManus, Man $_{7 r-8 r}$ ) 4 “This is how Chandaka submitted it.”

Apart from the examples given above, there is another word transcribed in Maitrisimit as ötüp $\left(\right.$ Maitr $\left._{103 / 2}\right)$. Although this was shown at the entry öt- "to request" in the Index (2019b: 448), it was interpreted as "passing through" in the Translation section (2019b: 266). While considering the possibility that the word may have the meaning of "to request", it is unfortunately not possible to clearly

$4 \quad$ The fragment containing the sentence is preserved in Germany and bears the registration number U 0002 (T II D 173 e). The relevant part is 'wytty on the eighth line on the front page of the fragment: published by Albert von Le Coq in 1909, was later published by Wilhelm Bang-Kaup in 1931 and by Zekine Özertural and Michael Knüppel in 2005. Bang-Kaup stated that the phrase ötti in the relevant line in the Notes section of the text means ötün-, that it has only been detected here so far and that it is "probably" a typo (Bang-Kaup, 1977: 266). In the Özertural \& Knüppel publication, the word was transcribed as öt $<\ddot{u} n>t i$ in accordance with this view (2005: 131).

Adres $\mid$ Address

RumeliDE Dil ve Edebiyat Araşturmalam Dergisi Osmanağa Mahallesi, Mürver Çiçeği Sokak, No:14/8 Kadıköy - ISTANBUL / TÜRKIYE 34714 e-posta: editor@rumelide.com

RumeliDE Journal of Language and Literature Studies Osmanağa Mahallesi, Mürver Çiçeği Sokak, No:14/8

Kadıköy - ISTANBUL / TURKEY 34714 tel: +90 $5057958124,+902167730616$

e-mail: editor@rumelide.com,

phone: +90 505 7958124, +90 2167730616 
state in which sense it is used in accordance with the context, since the relevant part of the text contains deficiencies.

Apart from all these, no other example could be found in any of the text reviews we made, showing that the verb was used in the sense sought here. As a result, we have only two sentences. Although, these sentences can easily be interpreted and do not create any doubt about the topic at hand, one of them belongs to a Buddhist text while the other contains Manichaean elements. In other words, they belong to different religious-cultural environments, and there is no data that allows us to think that the same spelling error was made on the same verb in both, and there is no data to prove this. Moreover, if there is such a spelling error, then what should be the base of words such as ötüg "wish, request" and the derivational ötügči "requester"? Let's leave these questions aside here for now and look at other languages besides Turkish where the verb can be found.

Another instrument that can help us with etymology is Mongolian, with which Turkish has interacted since ancient times. It is possible to determine the relevant verb as öči- in this language with the meanings of "to say, answer, testify; to pray, to offer (Buddhist)" (Lessing, 1960: 628b) as a loan word. Gustav John Ramstedt is one of the first to demonstrate this equivalence by comparing öc $\check{i}$ - in Mongolian with the verb ötün- in Old Uyghur and Chagatai Turkish (1935: 302b). Then, Nicholas Poppe made a similar comparison and envisioned a verb in the form of * $t i$ - regarding the base of the verb:

Mo. öči- < *öti- "to pray, to beg”, MMo öči- "to report" = OT ötüg "request, pray”, ötün- "to request" (Poppe, 1960: 51).

Orçun Ünal compared the words OT ötüg and CM öčig, as well as the equivalence of ötün- öči- and stated that there is no direct relationship between the words öčig and ötüg and that the first one derives from the verb öči- in Mongolian (2016: 573-574).

In the Secret History of the Mongols dating from 1240, one of the oldest written sources of Mongolian, the verb öc $i$ - is found with the meaning of "to notify, to inform" (Haenisch, 1939: 121). It is possible to exemplify this from different written sources as well. There are derivatives of the verb öči- in a document dating 1320 (Cleaves, 1953: 28), in a Chinese-Mongolian monument dating 1335 (Cleaves, 1950: 74) and in Phagspa written texts (Tumurtogoo, 2010: 18, 540). It was also detected in Huáyi yiy ǔ, which was started to be prepared during the Ming Dynasty (Mostaert, 1977: 8-10, IIb 1r $\mathrm{r}_{5}, \mathrm{IIb}_{7 \mathrm{r}_{2}}$ ).

It is seen that the verb is already alive in contemporary Mongolian languages. Although өчux (=öçih) has the meanings of "(1) To say. (2) To testify." in Khalkha Mongolian (Bawden, 1997: 282), In Kalmyk, another Mongolian language, it has such derivatives as $\ddot{o t} s^{\prime} \chi ə$ "to answer, defend oneself, explain" and öts ${ }^{\circ} G$ "answer, defense, objection to something”. (Ramstedt, 1935: 302b)

Considering that the consonant / $\check{c} /$, which precedes the vowels $* / 1 /$ and $/ \mathrm{i} /$ in Mongolian, is the equivalent of */t/ in Turkish (Ramstedt, 1903: 11-12; Poppe, 1956: 205; Poppe, 1960: 50) since Poppe onwards, * öti- is envisioned -as explained above- in which Mongolian verb öči- has developed. In this way, it becomes clear what kind of base the verb OT ötün- has, at least in the much older periods of Turkish. It is possible to think that after the First Turkish period, when the word final vowels disappeared, the verb base took the form of öt- in Turkish. However, this verb must be a different $\ddot{o} t$ from the others, which basically means "to make a request, to make a petition" because it is seen that its

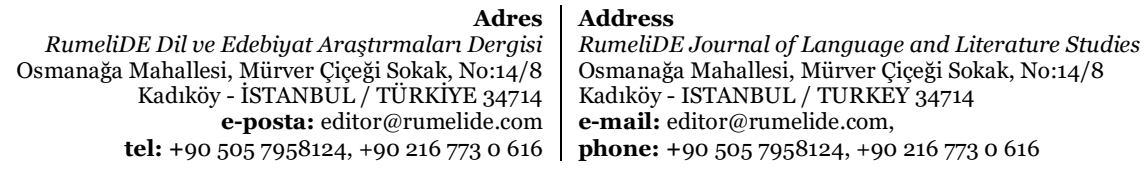


meaning is parallel to ötün- when the form in Mongolian is examined. ${ }^{5}$ Considering the form of the verb vidĕn- in Chuvash (Skvorcova, 1982: 82), it can be thought that it is actually used with the reflexive suffix $\{-\mathrm{n}\}$ in almost every period of the Turkish language.

\section{Derivatives of the verb öt- in historical Turkish dialects}

Ötüg (< öt-̈̈-g): Basically, it has meanings such as "submission, request, wish" and its first written example is found in Orkhon Turkish texts: yalabačı ädgü sabı ötügi kälmäz tiyin yayın sülädim (BK / E-39) "I sent the army in the summer, in case his envoy, good word and request would not come."

In the religious works of the Old Uyghurs, the word has played a role in hendiadys structures in addition to its individual uses: bo ötüg sav äs̆dip $\left(\mathrm{KP}_{\mathrm{XV}_{7}}\right)$ "Hearing this request..." alkıšm(l)z ötügümüz $t(\ddot{a})$ grikä arıın $t(\ddot{a}) g m a ̈ d i ~ a ̈ r s a ̈ r ~\left(H{ }^{2} t_{254-255}\right.$ ) “...if our praise and wishes did not reach God cleanly...”

In addition, the fact that it can be detected in documents in the form of a petition shows that the word was used almost like a term in the relevant period: buyančı bäglärim kutına muך ötüglüg kuluț p[intu]y öțügüm täginür (*Pam 011-4) "I, their pleading servant Pintuy, (my) request is submitted to the presence of my merciful lords." Likewise, the letters submitted to the higher authority are called ötüg bitig: amtı ötüg bitigdä nä üküšötüg ötünü tä[ginälim] (BT XLVI, K $7713 \mathrm{r}_{7}$ ) “Now let us respectfully present as many wishes as possible in this letter of request." There are examples where the word alone

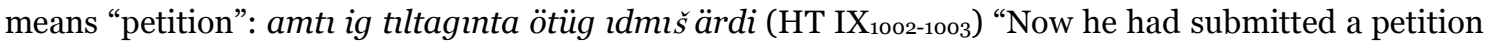
for the cause of death."

After the Old Uyghur Turkish, it is possible to trace the existence of the word until the period of Khwarazm Turkish. As witnessed in many verses of the KB (Arat, 2008: 1218), it was explained as "What is submitted to the Sultan, submission" in DLT (Ercilasun \& Akkoyunlu, 2014: 32). Finally, it should be noted that it is used with the same basic meaning in the masnavi of Kutb, Hüsrev ü Şirin (Hacieminoğlu, 2000: 241). It was seen that the word, which has a wide usage area in Central Asia and Iran, is quoted as ôtü̆g in Persian and as öcigu in Mongolian (Doerfer, 1965: 134).

Ötügči (< öt-ü-g-či): It can be identified with the meanings of "submitter, requester" in both Old Uyghur and Karakhanid Turkish texts (Clauson, 1972: 53a): bo nom ärdinig nomladačı nomčlka ötügči bolsunlar (AY Kaya ${ }_{530 / 14-16}$ ) "...let them be pleading to the preacher who conveys this jewel of teaching." Another compound verb that established with this word is ötügči tut-: ötügči tuta (BT XVIII ${ }_{842}$ ) "hold as petitioner..."

We can see with reference to the DLT that the word gained an Islamic identity with the Karakhanid Turkish period and was used in the sense of "intercessor" (Ercilasun \& Akkoyunlu, 2014: 274).

Ötügčilig (< öt-ü-g-či-lig): The word basically means "solicitation, intercession" and it is in a hendiadys with savčllk and ötüg sav: bo ačarilar ymä bitig [t]utup ötügčiligin savčlhg[l]n samsto ačarita töz nom[ug] bošgunup (HT VIII61-64) “...these masters also brought the book with them and learned the main teaching from Master Samsto by solicitation...”

\footnotetext{
5 Ötün- is associated with the verb öt- whose basic meaning is "to pass, to pierce, to penetrate" and the verb öt- that means "to sing, to tweet" and whose original version has long vowels. In such a case, we think that at least one of these meanings should be included in the Mongolian verb öči-. The fact that both öči- and ötün- basically mean "to request, to make a wish" allows to argue that there is a different kind of verb.

Adres Address

RumeliDE Dil ve Edebiyat Araştrrmalarn Dergisi $\quad$ RumeliDE Journal of Language and Literature Studies Osmană̆a Mahallesi, Mürver Cicçeği Sokak, No:14/8 Osmanağa Mahallesi, Mürver Çiçeği Sokak, No:14/8 Kadıköy - İSTANBUL / TÜRKIYE 34714 Kadıöy - ISTANBUL / TURKEY 34714 e-posta: editor@rumelide.com $\quad$ e-mail: editor@rumelide.com, tel: +90 $5057958124,+902167730616$ phone: +90 505 7958124, +90 2167730616
} 
Ötügčisiz (< öt-ü-g-či-siz): The word basically means "somebody without a petitioner, unsolicited": öțïgči-siz adın-larka umug bolaym $\left(\mathrm{ETS}_{9 / 108}\right)$ "Let me hope for those who have no intercessors.”

Ötügkiyä (< öt-ü-g-kiyä): The word means “modest, little request”. It is formed by adding the suffix $+k I y A$ that is frequently used in Old Turkish and adds reinforcement, reduction and love to the word to which it is added (Gabain, 1950: 155; Erdal, 1991: 48; Eraslan, 2012: 98): yalbarmıš öṭ̈g-kiyäm-ni äs̆d[ip] maya (BT XIII ${ }_{22.16}$ ) "To me hearing my humble request I beg..."

Ötüglüg (< öt-ü-g-lüg): It has almost the same meaning as ötügči above and it appears in Old Uyghur and Karakhanid Turkish texts just like it. However, it would not be wrong to assume that the word ötügči was used as a legal expression in the relevant periods, while the word ötüglüg is mostly included in religious texts. The reason for this view is that it is found at the beginning of a document in the form of a petition in the Old Uyghur (see ötüg) and that the phrase ötüglüg kišs in the DLT is explained as "one who has something to submit to the Khan" (Ercilasun \& Akkoyunlu, 2014: 78).

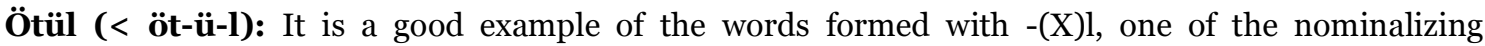
derivational suffixes that are not used very often in the Turkish and also seen in Mongolian (Gabain, 1950: 72; Erdal, 1991: 330; Hacieminoğlu, 1997: 50; Eraslan, 2012: 106). Besides, according to Vásáry, the form must have taken due to the influence of the Mongolian technical term öčl "application" (1995: 482). It was witnessed a few times in the yarliks of the Crimean khans that belong to the Golden Horde field: oțülin yöp korüp muḥammäd bizin soyurḳal bolup tarhhan bolup (AOY II $_{19-20}$ ) “...considering his request, let Muhammad be tarhan as our gift...”

Ötün (< öt-ü-n): It appears many times in Shajara-i Tarākima, one of the works of the Chagatai Turkish period. However, as it was not found in previous historical periods, the frequency of use is not very high in Chagatai (Kargı Ölmez, 1996: 273). In addition to its individual uses in the work, it formed a compound verb with the auxiliary verb kıl- in the meaning of "to request": här kaysısı bir türlük vä

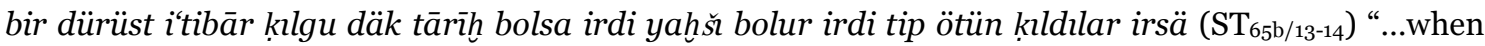
each of them presented that it would be nice if there was a date that would be respected and right...”

Ötünč (< öt-ü-n-č): Ötünč, whose basic meaning is "submission, request, wish”, appears for the first time in this sense in inscriptions just like ötüg: kaganım bän özüm bilgä tunukuk ötüntük ötünčümün äs̆dü birti (T I / S-8) "My khan myself listened to the exposure submitted by Bilge Tunyukuk.”

It can be said that the word has not been found in the Old Uyghur Turkish texts so that the same meaning ötüg has reached a wider usage area. However, ötünč appears again and this time with a different meaning from the Karakhanid period. Kashgari recorded this as a word used in the Oghuz dialect with the meaning of "loan, debt": mäy ayar yarmak ötünč bïrdim "I lent him one yarmak." (Ercilasun \& Akkoyunlu, 2014: 532).

In the dictionaries of Khwarazm, Kipchak and Chagatai Turkish, the word is explained in line with this second meaning:

Mukaddimetü'l-Edeb: borč / ötünč (18/2).

Kitābu Bulyatü'l-müțtāk fì Luyāti't-Türk ve’l-Kufčāk: ödinč “loan” (12a/1)

Kitāb-ı Mecmū-ı Tercümān-ı Türkī ve Acemī ve Muүalī: ödünč “loan” (38b/9)

Abuška: ötünč ödünč dämäkdür karż mánāsına (54/a).

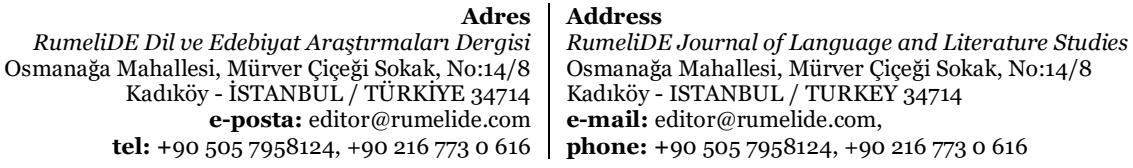


From the beginning of the Old Anatolian Turkish period, it is seen that the consonant of the middle syllable of the word was written voiced in the form of ödünč ödinč -as in the Kipchak dictionaries- : kamu halkı söylä gäčärlärdi dinč / ki bulınmaz olmıšdı zaḥmät ödinč $\left(\mathrm{SN}_{4547}\right)$ "All his people would live in calmness, free of troubles and debts.” kimdür šl ol kim ödünč virä tanryya ödünč virmäk görklü pes

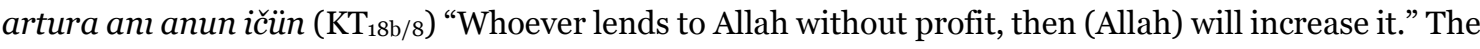
word continues to exist in the same way in Turkey Turkish today (Türkçe Sözlük, 2011: 1837).

According to Clauson, there are two different ötünčs meaning "submission, request" and "lend, debt"; the first of these is derived from the verb ötün- and the other one is derived from the verb *ötän- (ödän). (1972: 61a). Erdal stated that this is not possible, because although the second vowel is found to be round in many Middle Turkish sources and modern Turkish dialects, the suggestion of Clauson is nowhere to be found. He also emphasized that the word must have been derived from the verb ötün-, and stated that this is a result of the figurative expansion of the basic meaning of the verb (1991: 281). I also believe that there is no need for the distinction made by Clauson, because there is no such word in the historical texts as ötänč ödänč, and ötünč may have been used semantically as the equivalent of a debt received by requesting and asking (cf. ötünü ötnü).

I think that the existence of ötünč in the form of ödünč in Western Turkish is based only on the analogical effect of the verb öd $\ddot{a}$ - that is close to itself in terms of form and meaning. It does not seem possible to talk about any correlation other than this effect.

Ötündürül- (< öt-ün-dür-ü-l-): It means ötündürül- "to be demanded, wanted" formed by adding \{tUr\} causative and \{-1\} passivity suffixes to the verb ötün-: upalı sudur-ta ötündürülmiš ugan arșı öz-ä

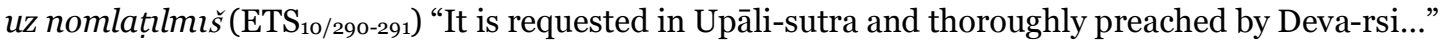

Ötüngän (< öt-ü-n-gän): It is another word we learn from the yarlik or bitigs belonging to Golden Horde and Crimea. Located in a bitig belonging to Nur Devlet Han, one of the Crimean khans, this

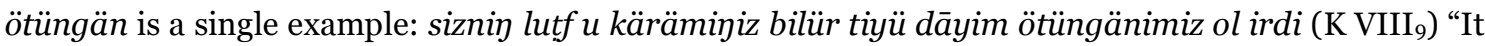
was always our submission, just in case your generosity knows.”

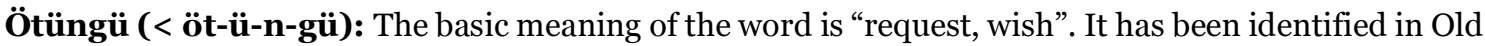

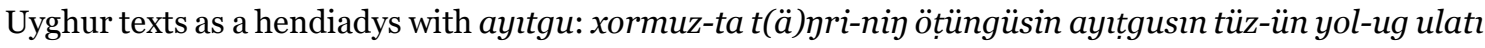

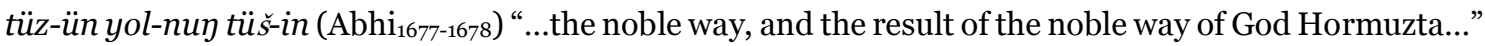

Ötünmäk (< öt-ü-n-mäk): The word is the infinitive form of the verb ötün-: altun öylüg y(a)ruklug

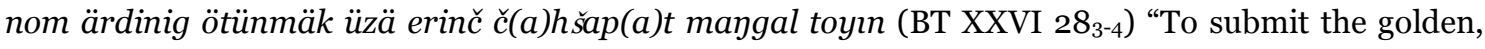
illuminated jewel of the law, the miserable Chahshapat Mangal Toyı...”

Ötüntür- (< öt-ü-n-tür-): It means ötündür- "to make someone ask for, to make a request" (Erdal, 1991: 822), one of the hapax in the Old Uyghur texts: anta basa yumıšč tıtsi-ka manțal ötün-dürüp (BT VII, A 387) "After that, he asked for mandala to the disciple who served and..."

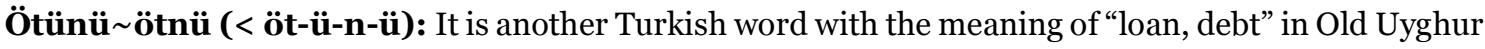
and Karakhanid Turkish texts. Clauson stated that the word ötnü, which he cited as an example from DLT, was formed by the abbreviation of the verb *ötän-, the reflexive form of the verb ötä- (1972: 6ob). In this respect, it is understood that both the words ötünč and ötnü go back to the same verb base for their etymology. However, some of the Old Uyghur loan agreements have sentences that will enlighten us on this issue:

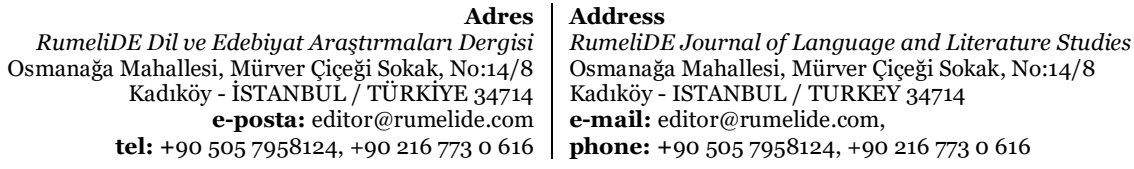




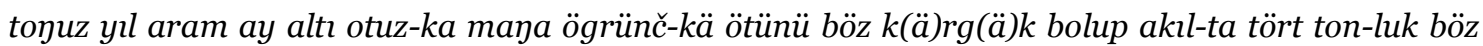
ötünü altım (*U 9000 ${ }_{1-3}$ ) "On the twenty-sixth of the first month of the year of the Pig, I borrowed four clothes of böz [...] when böz is necessary (as a loan) for Ögrünč.” yzlan yıl ikinți ay on iki-kä maya rrsulka ötünü bugday k(ä)rgäk bolup yabagu-ton (SI Kr. I/1471-3) "On the twelfth of the second month of the year of the Snake, wheat is required (as a loan) to me, Irsul, from Yabagu...”

I think the word ötünü and ötnü in the examples above are directly related not only in terms of semantics but also in terms of etymology, and it occurred through the deletion of the unstressed high vowel in the middle syllable of the first word. In addition, the proof that the Old Uyghur form becomes a noun with the lexicalization of the deverbal adverbial suffix is that the word ötnü is a noun meaning "debt". As a result, ötnü in Karakhanid Turkish is not based on the verb *ötän-, but on the word ötünü "loan, debt", so each of them is actually based on the verb ötün-.

If we go back to Karakhanid Turkish, it is seen that Kashgari recorded the word ötnü with the meaning of "loan, debt" in DLT and cited the sentence män yarmak ötnü bïrdim as an example (Ercilasun \& Akkoyunlu, 2014: 66). Apart from this, there is the compound verb ötnü al- meaning "to borrow" in KB: nägü ötnü alsa yana birsä tärk / ajar birgälär näy kačan kolsa tärk $\left(\mathrm{KB}_{2805}\right)$ "Whatever he borrows and pays on time, they will immediately give him the goods he wants."

\section{Conclusion}

Up to now, many views have been put forward for the base of the verb ötün- that has the basic meaning of "to submit, to request, to want". However, in order to reach a better conclusion on the subject, it is a necessity to use the Mongolian equivalent, the verb öči-, because there is not enough data. I think it is a more correct approach to conceive the verb base as öt- based on the sound equivalences between Mongolian and Turkish and words such as ötüg. It is also necessary to emphasize the possibility that the verb öt-, which appears only twice in Old Uyghur texts, is an example of an abbreviation rather than a spelling error. Nevertheless, when compared with the meanings of the form in Mongolian, it shows up that the verb is not related to the verbs öt- meaning "to pass, to pierce" and "to sing" which have various spelling in the texts, however, there is another verb öt- meaning "to submit, to request". As a result, a total of fifteen derivatives have been identified in the texts of historical Turkish dialects based on the related verb base. While the majority of these have meanings with the concept of "submission" and "request", it gained such meanings as ötünč and ötünü, "loan, debt" and became almost a commercial term.

\section{Abbreviations}

Abhi: Uighur Abhidharma Texts, Shōgaito 2008

AH: Atebetü'l-Hakaylk, Arat 2006

AOY: Yarlik and bitigs of the Altın Ordu (Golden Horde), Özyetgin 1996

AY Kaya: Altun Yaruk, Kaya 1994

BK: Bilge Kagan Inscription, Ercilasun 2016

BT VII: Berliner Turfantexte VII, Kara \& Zieme 1976

BT XIII: Berliner Turfantexte XIII, Zieme 1985

BT XVIII: Berliner Turfantexte XVIII, Zieme 1996

BT XXVI: Berliner Turfantexte XXVI, Kasai 2008

$$
\begin{aligned}
& \text { Adres } \mid \text { Addres } \\
& \text { RumeliDE Dil ve Edebiyat Araşttrmaları Dergisi } \quad \text { RumeliDE Journal of Language and Literature Studies } \\
& \text { Osmanağa Mahallesi, Mürver Çiçeği Sokkak, No:14/8 } \quad \text { Osmanağa Mahallesi, Mürver Çiçeği Sokak, No:14/8 } \\
& \text { Kadıköy - İSTANBUL / TÜRKIYE } 34714 \text { Kadıö̈y - ISTANBUL / TURKEY } 34714 \\
& \text { e-posta: editor@rumelide.com } \quad \text { e-mail: editor@rumelide.com, } \\
& \text { tel: +90 505 7958124, +90 } 216773 \text { o } 616 \text { phone: +90 505 7958124, +90 } 2167730616
\end{aligned}
$$


BT XLVI: Berliner Turfantexte XLVI, Moriyasu 2019

ChristManMus: Le Coq 1909.

DLT: Dīwān Luyāt at-Turk, Ercilasun \& Akkoyunlu 2014

DS: Derleme Sözlüğü

DTS: Drevnetjurkskij Slovar', Nadaljaev et al. 1969

E: East

ED: An Etymological Dictionary of Pre-thirteenth Century Turkish, Clauson 1972

ETS: Eski Türk Şiiri, Arat 2007

GT: Chagatai translation of the Gülistan, Berbercan 2011

HT VIII: Hsüen-Tsang, Röhrborn 1996

HT IX: Hsüen-Tsang, Aydemir 2010

Huast : Huastuanift, Özbay 2014

IU: Istanbul University

K: Yarlik and bitigs of the Kırım (Crimea), Özyetgin 1996

KB: Kutadgu Bilig, Arat 2008

KE: Ḳıșașü’l-Enbiyā, Ata 1997

KP: The Story of Prince Kalyanamkara and Papamkara, Hamilton 1998

KT: Kur'an Translation in Old Anatolian, Topaloğlu 1976

KuanTekin: Kuanți im Pusar, Tekin 2019a

KY: Kıssa-i Yûsuf, Cin 2011

Maitr: Maitrisimit, Tekin 2019b

OTWF: Old Turkic Word Formation, Erdal 1991

S: South

SN: Süheyl ü Nev-bahar, Dilçin 1991

ST: Shajara-i Tarākima, Kargı Ölmez 1996

T I: Tunyukuk Inscription, 1 $^{\text {st }}$ Stone, Ercilasun 2016

Tar.: Tariat Inscription, Ölmez 2013

TDK: Türk Dil Kurumu (= Turkish Language Association)

TS: Tarama Sözlüğü

TTK: Türk Tarih Kurumu (= Turkish Historical Society)

Bibliography

Al-Turk, G. A. (2012). Kitābu Bulġatu'l-Muştāk fi Luġatit't-Türk we'l-Klfçāk ÜZzerine Dil İncelemesi. Unpublished PhD. Thesis. Gazi University, Institute of Social Sciences, Department of Turkish Language and Literature. Ankara.

Arat, R. R. (2006). Edib Ahmed B. Mahmud Yükneki. Atebetü’l-Hakayık. $3^{\text {rd }}$ Edition. Ankara: TDK.

Arat, R. R. (2007). Eski Türk Şïri. $4^{\text {th }}$ Edition. Ankara: TTK.

Arat, R. R. (2008). Yusuf Has Hacib. Kutadgu Bilig. $2^{\text {nd }}$ Edition. Istanbul: Kabalc1.

Ata, A. (1997). Kııșașü’l-Enbiyā (Peygamber Kıssaları) I-II. Ankara: TDK.

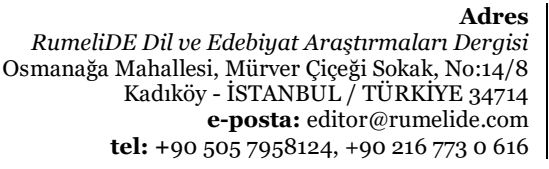

dres

RumeliDE Journal of Language and Literature Studies

Osmanağa Mahallesi, Mürver Çiçeği Sokak, No:14/8

Kadıköy - ISTANBUL / TURKEY 34714

e-mail: editor@rumelide.com,

phone: +90 $5057958124,+902167730616$ 
Aydemir, H. (2010). Die alttürkische Xuanzang-Biographie IX. Nach der Handschrift von Paris, Peking und St. Petersburg sowie nach dem Transkript von Annemarie v. Gabain ediert, übersetzt und kommentiert. Dissertation zur Erlangung des Doktorgrades der Philosophischen Fakultät der Georg-August-Universität Göttingen. Göttingen.

Bang-Kaup, W. (1931). Manichäische Erzähler. Le Muséon 44, 1-36. [Reprint: Bang-Kaup, W. (1977). Manichäische Erzähler. In Geo Widengren (Ed.), Der Manichäismus (pp. 260-286). Darmstadt: Wissenschaftliche Buchgesellschaft.]

Baskakova, N. A. (1958). Karakalpaksko-russkij slovar'. Moskva: Gosudarstvennoje izdatel'stvo inostrannyx i nacional'nyx slovarej.

Baskakova, N. A. (1968). Turkmensko-russkij slovar'. Moskva: Sovetskaja enciklopedija.

Bawden, C. (1997). Mongolian-English Dictionary. London and New York: Kegan Paul International.

Berbercan, M. T. (2011). Çağatayca Gülistan Tercümesi (Gramer-Metin-Dizin). Unpublished PhD. Thesis. Istanbul University, Institute of Social Sciences, Department of Turkish Language and Literature. Istanbul.

Borovkova, A. K. (1959). Uzbeksko-russkij slovar'. Moskva: Gosudarstvennoje izdatel'stvo inostrannyx i nacional'nyx slovarej.

Caferoğlu, A. (1968). Eski Uygur Türkçesi Sözlüğü. Istanbul: TDK.

Cin, A. (2011). Türk Edebiyatının İlk Yûsuf ve Züleyhâ Hikâyesi, Ali’nin Kıssa-yı Yûsuf'u. Ankara: TDK.

Clauson, Sir G. (1972). An Etymological Dictionary of Pre-thirteenth Century Turkish. Oxford: Clarendon Press.

Cleaves, F. W. (1950). The Sino-Mongolian Inscription of 1335 in Memory of Chang Ying-Jui. Harvard Journal of Asiatic Studies 13(1/2), 1-131.

Cleaves, F. W. (1953). The Mongolian Documents in the Musée de Téhéran. Harvard Journal of Asiatic Studies 16(1/2), 1-107.

Demirci, Ü. Ö. (2016). Eski Türkçede Fïller. Kocaeli: Umuttepe.

Dilçin, C. (1991). Mes'ūd bin Ahmed Süheyl ü Nev-Bahar İnceleme-Metin-Sözlük. Ankara: Atatürk Kültür Merkezi.

Doerfer, G. (1965). Türkische und Mongolische Elemente im Neupersischen Band II. Wiesbaden: Franz Steiner.

Eraslan, K. (2012). Eski Uygur Türkçesi Grameri. Ankara: TDK.

Ercilasun, A.B. and Z. Akkoyunlu (2014). Kâssgarh Mahmud. Dîvânu Lugâtitt-Türk. Ankara: TDK.

Ercilasun, A. B. (2016). Türk Kağanlı̆̆ı ve Türk Bengü Taşları. Istanbul: Dergâh.

Erdal, M. (1991). Old Turkic Word Formation. Turcologica VII. Wiesbaden: Otto Harrassowitz.

Erdal, M. (2004). A Grammar of Old Turkic. Leiden: Brill.

Gabain, A. v. (1950). Alttürkische Grammatik. Leipzig: Otto Harrassowitz.

Hacıeminoğlu, N. (1997). Harezm Türkçesi ve Grameri. Ankara: İ̈̈ Edebiyat Fakültesi Yayınları.

Hacieminoğlu, N. (2000). Kutb’un Husrev ü Şirin’i ve Dil Hususiyetleri. Ankara: TDK.

Haenisch, E. (1931). Wörterbuch zu Manghol un Niuca Tobca'an (Yüan-Ch'ao Pi-shi) Geheime Geschichte der Mongolen. Leipzig: Otto Harrassowitz.

Hamilton, J. R. (1998). Budacı İyi ve Kötü Kalpli Prens Masalını Uygurcası. (Transl. Ece Korkut, İsmet Birkan). Türk Dilleri Araştırmaları Dizisi: XI. Ankara: Simurg.

Judaxin, K. K. (1985). Kirgizsko-russkij slovar' I-II. Moskva: Sovetskaja enciklopedija.

Kaçalin, M. S. (2011). Nevâŷ̂nin Sözleri ve Çağatayca Tanıklar. Ankara: TDK.

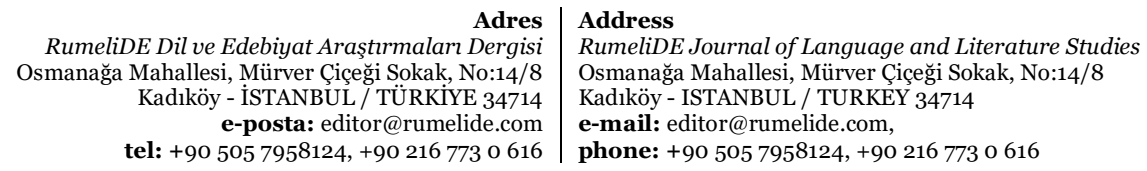


Kara, G. and P. Zieme (1976). Fragmente tantrischer Werke in uigurischer Übersetzung. BT VII. Berlin: Akademie Verlag.

Kargı Ölmez, Z. (1996). Ebulgazi Bahadır Han. Şecere-i Terākime (Türkmenlerin Soykütüğü). Türk Dilleri Araştırmaları Dizisi: III. Ankara: Simurg.

Kasai, Y. (2008). Die uigurischen buddhistischen Kolophone. BT XXVI. Turnhout: Brepols.

Kaya, C. (1994). Uygurca Altun Yaruk Giriş, Metin ve Dizin. Ankara: TDK.

Le Coq, A. v. (1909). Ein christliches und ein manichäisches Manuskriptfragment in türkischer Sprache aus Turfan (Chinesisch-Turkistan). Sitzungsberichte der Königlich Preußischen Akademie der Wissenschaften XLVIII, 1202-1218.

Lessing, F. D. (1960). Mongolian-English Dictionary. Berkeley and Los Angeles: University of California.

Moriyasu, T. (2019). Corpus of the Old Uighur Letters from the Eastern Silk Road. BT XLVI. Turnhout: Brepols.

Mostaert, A. (1977). Le Matériel Mongol du Houa I I IU 華夷譯語 de Houng-ou (1389). Igor de Rachewiltz, Anthony Schönbaum (Eds.). Mélanges Chinois et Bouddhiques Vol. XVIII. Bruxelles: Institut Belge des Hautes études Chinoises.

Nadaljaev et al. (1969). Drevnetjurkskij slovar'. Leningrad: Nauka.

Necip, E. N. (1995). Yeni Uygur Türkçesi Sözlüğ̈̈. (Transl. İklil Kurban). Ankara: TDK.

Ölmez, M. (2013). Orhon-Uygur Hanlı̆̆ Dönemi Moğolistan'daki Eski Türk Yazıtları, Metin-ÇeviriSözlük. Ankara: BilgeSu.

Ölmez, M. (2017). Eski Uygurca ikilemeler üzerine. Türk Dili Araştırmaları Yillı̆̆ı-Belleten 65(2), 243311.

Öner, M. (2009). Kazan-Tatar Türkçesi Sözlüğü. Ankara: TDK.

Özbay, B. (2014). Huastuanift Manihaist Uygurlarm Tövbe Duası. Ankara: TDK.

Özertural, Z. and M. Knüppel (2005). Zu den Eigennamen im Fragment einer manichäisch-türkischen Buddhavita. Studia Etymologica Cracoviensia X, 123-139.

Özşahin, M. (2017). Başkurt Türkçesi Sözlüğü. Ankara: TDK.

Özyetgin, A. M. (1996). Altın Ordu, Kırım ve Kazan Sahasına Ait Yarlkk ve Bitiklerin Dil ve Üslûp İncelemesi. Ankara: TDK.

Poppe, N. (1956). The Mongolian Affricates *č and *3. Central Asiatic Journal 2/3, 204-215.

Poppe, N. (1960). Vergleichende Grammatik der Altaischen Sprachen, Teil 1 Vergleichende Lautlehre. Wiesbaden: Otto Harrassowitz.

Ramstedt, G. J. (1903). Das schriftmongolische und die Urgamundart phonetisch verglichen. Journal de la Société Finno-Ougrienne 21(2), 1-56.

Ramstedt, G. J. (1935). Kalmückisches Wörterbuch. Helsinki: Suomalais-Ugrilainen Seura.

Röhrborn, K. (1996). Die alttürkische Xuanzang-Biographie VIII. Nach der Handschrift von Paris, Peking und St. Petersburg sowie nach dem Transkript von Annemarie v. Gabain hrsg., übersetzt und kommentiert. VdSUA 34. Wiesbaden: Harrassowitz.

Sevortjan, E. V. (1974). Ètimologičeskij slovar' tjurkskih jazykov. Obțčetjurkskie i meẓtjurkskie osnovy na glasnye. Moskva: Nauka.

Shnitnikov, B. N. (1966). Kazakh-English Dictionary. London-The Hauge-Paris: Mouton \& Co.

Shōgaito, M. (2008). Uighur Abhidharma Texts: A Philological Study. Kyoto: Shoukadoh.

Skvorcova, M. I. (1982). Čuvațsko-russkij slovar'. Moskva: Russkij jazyk.

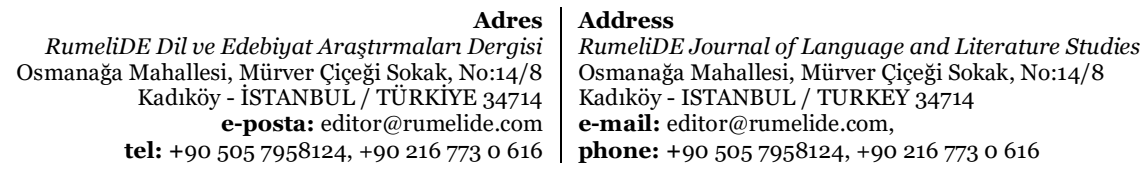


Şen, S. (2002). Eski Uygur Türkçesinde İkilemeler. Unpublished Master Thesis. Ondokuz Mayıs University, Institute of Social Sciences, Department of Turkish Language and Literature. Samsun.

Tarama Sözlüğ̈̈ I-VIII (1995). $3^{\text {rd }}$ Edition. Ankara: TDK.

Tekin, Ş. (2002). Eski Türkçe. In Türk Dünyası El Kitabı İkinci Cilt: Dil-Kültür-Sanat (pp. 69-119). $3^{\text {rd }}$ Edition. Ankara: TKAE.

Tekin, Ş. (2019a). Uygurca Metinler I Kuanşi İm Pusar (Ses İşiten İlâh). $2^{\text {nd }}$ Edition. Ankara: TDK.

Tekin, Ş. (2019b). Uygurca Metinler II Maytrısimit. Burkancıların Mehdîsi Maitreya ile Buluşma. Uygurca İptidaî Bir Dram. Ankara: TDK.

Tekin, T. (2003). Orhon Türkçesi Grameri. $3^{\text {rd }}$ Edition. Türk Dilleri Araştırmaları Dizisi: IX. Istanbul.

Topaloğlu, A. (1976). XV. Yüzyıl Başlarında Yapılmış “Satır-Arası” Kur’an Tercümesi. Istanbul: Devlet Kitapları.

Toparlı, R. et al. (2000). Kitâb-ı Mecmû-ı Tercümân-ı Türkî ve Acemî ve Mugalî. Ankara: TDK.

Tulum, M. M. (2015). Geçmişten Günümüze öykün- Fiili Üzerine. In A. Azmi Bilgin et al. (Eds.), XI. Milli Türkoloji Kongresi (11-13 Kasım 2014) Bildirileri Vol. I (pp. 469-475). Istanbul: Istanbul Büyükşehir Belediyesi.

Tumurtogoo, D. (2010). Mongolian Monuments in 'Phags-pa Script. Taipei: Institute of Linguistics, Academia Sinica.

Türkçe Sözlük (2011). 11 ${ }^{\text {th }}$ Edition. Ankara: TDK.

Türkiye'de Halk Ağzından Derleme Sözlüğ̈̈ I-VI (2019). Jointed $4^{\text {th }}$ Edition. Ankara: TDK.

Ünal, O. (2016). Klasik Moğolca Söz Varlı̆̆ıda Türkçe Kökenli Kelimeler ve Türkçe-Moğolca Ses Denklikleri. Unpublished PhD. Thesis. Marmara University, Institute of Turkic Studies, Department of Turkish Language and Literature. Istanbul.

Vásáry, I. (1995). Mongolian Impact on the Terminology of the Documents of the Golden Horde. Acta Orientalia Academiae Scientiarum Hungaricae XLVIII (3), 479-485.

Wilkens, J. (2021). Handwörterbuch des Altuigurischen (Altuigurisch-Deutsch-Türkisch). Göttingen: Universitätsverlag Göttingen.

Yüce, N. (2014). Mukaddimetü’l-Edeb. Hvārizm Türkçesi ile Tercümeli Şuşter Nüshası. $3^{\text {rd }}$ Edition. Ankara: TDK.

Zieme, P. (1985). Buddhistische Stabreimdichtungen der Uiguren. BT XIII. Berlin: Akademie Verlag.

Zieme, P. (1996). Altun Yaruq Sudur. Vorworte und das erste Buch. Edition und Übersetzung der alttürkischen Version des Goldglanzsūtra (Suvarnaprabhāsottamasūtra). BT XVIII. Turnhout: Brepols.

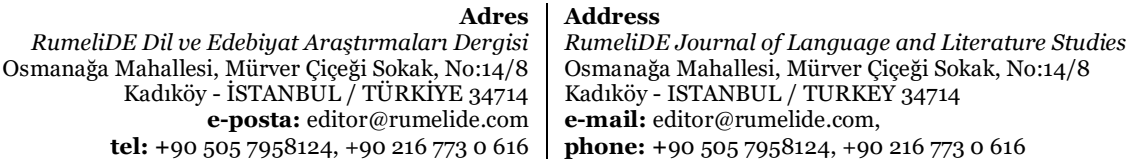

